\title{
Effect of salicylic acid, moringa leaves extract and seaweed extract on growth, yield and quality of roselle, Hibiscus sabdariffa L., under Aswan conditions
}

\author{
Zakria Y., ${ }^{1}$ S.S.A. Abdel-Rahman ${ }^{2}$, W.S. Soliman, ${ }^{1, *}$, S. Salahelidn ${ }^{1}$ \\ ${ }^{1}$ Horticulture Department, Faculty of Agriculture and Natural Resources, Aswan University, Aswan, \\ Egypt. \\ ${ }^{2}$ Horticulture Department, Faculty of Agriculture, Assiut University, Assiut, Egypt
}

\begin{abstract}
Bio-stimulants play a vital role in the sustainable development of horticultural crops. The aim of this study was to assess the effect of synthesis stimulator (salicylic acid) and bio-stimulants (moringa extract, seaweed extract) on growth, yield and quality of Roselle, Hibiscus sabdariffa L., plants. The recorded growth parameter included plant height, number of lateral branches per plant, branch diameter, and leaf area. For yield traits, the calyxes' fresh and dry weight was recorded. Leaf pigments included chlorophyll a, b, and carotenoids. Anthocyanin content in calyxes was measured. The experiment was conducted during 2018 and 2019 seasons, and was designed in completely randomized system. The results showed that application of bio-stimulants showed positive effects on all traits, and the best results were shown under treatment of seaweed, followed by moringa leaves extract. There were positively associations of calyxes yield and its anthocyanin content with other growth traits and photosynthetic pigments. These results highlighted the important role of biostimulants, especially seaweed extract, as a bioactive stimulant. Therefore, it is recommended to include seaweed extract in fertilization programs for achieving sustainable production system of such crops.
\end{abstract}

Keywords: Anthocyanin; Moringa extract; Roselle plant; Salicylic acid; Seaweed extracts.

\section{Introduction}

Natural and synthetic growth stimulators play an important role in promoting growth and development of crops. For decades, such plant growth stimulators have been used extensively in crop production, whether by soil application or foliar spraying. Plant stimulators have positive effects not only on plant growth and nutrition, but also on abiotic

*Corresponding author: W.S. Soliman

Email: wagdi79@agr.aswu.edu.eg

Received: December 6, 2020

Accepted: December 19, 2020

Published: December 26, 2020 and biotic stress tolerance (du Jardin, 2015). For example, salicylic acid as a synthetic stimulator regulates several functions in plant including plant resistance to environmental stresses such as drought and salinity (Arfan et al., 2007) and chilling (Farooq et al., 2008). In addition, natural plant bio-stimulants are important in sustainable horticulture production systems. There are several studies that have reviewed the role of bio-stimulants in relation to promoting growth and nutrient availability (Colla and Rouphael, 2015; du Jardin, 2015). In addition to numerous studies 
that have reviewed broadly defined categories of bio-stimulants such as protein hydrolysates, seaweed extracts, silicon, chitosan, humic acid, and fulvic acid (Van Oosten et al., 2017). The results showed the positive effects of seaweed on plant productivity and quality (Layek et al., 2017; Pramanick et al., 2017; Mzibra et al., 2018). This is in addition to the beneficial effects of seaweed extracts, including betaines, polysaccharides, amino acids, polyamines, and vitamins (Lötze and Hoffman, 2015; Singh et al., 2015). Other studies demonstrated the impact of seaweed extracts on plant stress tolerance, including biotic and abiotic stresses (Mansori et al., 2014; Arioli et al., 2015). On the other hand, moringa leaf extracts positively improve seeds germination, plant growth and yield, nutrient use efficiency, crop quality characters, as well as tolerance to environmental stresses (AbdelRahman and Abdel-Kader, 2020; Zulfiqar et al., 2020).

Roselle (Hibiscus sabdariffa L.) plant is a botanical species belonging to the Malvaceae family. It is probably native to a tropical central and west of Africa, and it is recognized as tropical and sub-tropical shrub (Dhar et al., 2015). Roselle plays an important role in income and subsistence providing for rural farmers in developing countries. The part of the plant used for nutritional and medicinal purposes is the calyxes, which have nutritional values and medicinal benefits. Roselle calyxes are rich in nutrients such as anthocyanins, organic acids, pectin, phenolic compounds and vitamins. It is commonly used for reducing chronic diseases (Wu et al., 2018), as well as acts as an antimicrobial (Khalaphallah and Soliman, 2014).

Natural and synthetic growth stimulators play an important role in the sustainable management of horticultural crops. The aim of this experiment was to examine the effects of salicylic acid, moringa leaves extract as well as seaweed extract on the vegetative growth, yield and quality of Roselle, Hibiscus subdariffa L., plants. The hypothesis of this study is that bio-stimulants are effective alternatives to mineral fertilizers especially under organic farming system.

\section{Material and methods}

The present study was carried out during the two successive seasons of 2018 and 2019 at Agricultural Experimental Farm, Faculty of Agriculture and Natural Resources, Aswan University, Sahary city, Aswan, Egypt. Seeds of Roselle (Sobahia dark variety) were obtained from the Agricultural Research Centre, Giza, Egypt, and were directly sown in the field on $15^{\text {th }}$ of April of each year. The experiment was designed in a completely randomized complete design with four replicates. Four treatments were used; moringa leaves extract (5\%), Seaweed extract (0.3\%), Salicylic acid (400 ppm) as well as control. Each experimental unit (plot) included two rows, $50 \mathrm{~cm}$ apart and $3 \mathrm{~m}$ length. The seeds were sown in hills, $30 \mathrm{~cm}$ apart, with a total of 20 plants in each plot. Drip irrigation system was used for irrigation purpose and normal agricultural practices were carried out. The treatments were foliar spraying at three times; at 45, 75, and 105 days from planting. The plants were harvested during October of each year, and the data has been collected.

\section{Vegetative growth and yield traits}

The vegetative growth parameters were recorded including plant height $(\mathrm{cm})$, number of lateral branches per plant disturbed on the main branch, branch diameter $(\mathrm{cm})$, and leaf area $\left(\mathrm{cm}^{2}\right)$. For yield traits, the calyxes were separated and fresh weight per plant were 
recorded, then calyxes were air dried in shade conditions for one week, and dry weight per plant were recorded. The total yield of fresh and dry calyxes was calculated per Fadden (one Fadden equals to $4200 \mathrm{~m}^{2}$ ).

\section{Photosynthetic pigments:}

Samples of fresh leaves were randomly collected from the mid-part of plants of each treatment in the early morning. Leaf pigments were measured by extraction of $50 \mathrm{~g}$ fresh leaves by $10 \mathrm{~mL}$ acetone $80 \%$. The developed color was colorimetrically determined using SPECTROstar Nano (BMG LAbTECH $\mathrm{GmbH}$, Germany) at wave length of 663,644 and $452.5 \mathrm{~nm}$ according to Metzner et al. (1965). Chlorophyll "a", "b", and carotenoids contents were calculated taking into consideration the dilution factor. The concentration of pigment fractions was determined as $\mathrm{mg} / \mathrm{ml}$ using the following equations:

Chlorophyll "a" =10.3E663 - 0.918E644

Chlorophyll "b" =19.7E644 - 3.87E663

Carotenoids $=4.2 \mathrm{E} 452.5-(0.0264 \mathrm{Chl} . \mathrm{a}+$ 0.426 Chl.b)

Finally, the pigment fractions were calculated as $\mathrm{mg} / \mathrm{g}$ fresh weight of leaves.

\section{Determination of total anthocyanin}

Anthocyanin content in calyxes was determined according to Lee et al. (2005). This method is based on the monomeric anthocyanin pigments reversibly changing color with a change in $\mathrm{pH}$; the colored

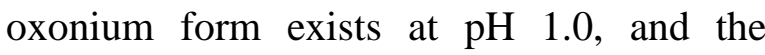
colorless hemiketal form predominates at $\mathrm{pH}$ 4.5. The difference in the absorbance at 520 $\mathrm{nm}$ at those two $\mathrm{pH}$ is proportional to the pigment concentration.

Known weight (200 mg) of air-dried calyxes was extracted using extraction solution $(15 \mathrm{ml}$ methanol $75 \%$ acidic with hydrochloric acid
$1 \%$ ) and incubated overnight at $4{ }^{\circ} \mathrm{C}$ in the dark. The buffer solution (sodium acetate, $\mathrm{pH}$ 4.5) was added to $1 \mathrm{ml}$ extraction, and the buffer solution (potassium chloride, $\mathrm{pH}$ 1.0) was added to another $1 \mathrm{ml}$ extraction. The absorption of anthocyanin was colorimetrically measured at both $\mathrm{pH}$ at 520 and $700 \mathrm{~nm}$ using SPECTROstar Nano (BMG LAbTECH GmbH, Germany). The absorbance was measured within 20-50 min of preparation, and acidic methanol was used as blank.

The concentration of anthocyanin was calculated in the samples and expressed as cyanidin-3-glucoside (Cyd-3-Glu) equivalents $(\mathrm{mg} / 100 \mathrm{~g})$, as follows:

\section{$A \times M W \times D F \times 1000$}

$\in \times 1$

where $\mathrm{A}=(\mathrm{A} 520 \mathrm{~nm}-\mathrm{A} 700 \mathrm{~nm}) \mathrm{pH} 1.0-$ $(\mathrm{A} 520 \mathrm{~nm}-\mathrm{A} 700 \mathrm{~nm}) \mathrm{pH}$ 4.5; MW (molecular weight $)=449.2 \mathrm{~g} / \mathrm{mol}$ for Cyd-3Glu; $\mathrm{DF}=$ dilution factor $=1.5 ; 1=$ path length in $\mathrm{cm} ; \epsilon=26,900$ molar extinction coefficient of Cyd-3-Glu.

\section{Statistical analysis:}

Data were subjected to statistical analysis using one-way ANOVA. The least significant differences (L.S.D.) was used to analyze significance among the mean values of these parameters (Snedecor and Cochran, 1989). All statistical analyses were carried out using JMP (ver 4. SAS Institute, Cary, NC, USA).

\section{Results and discussion}

It was clear that spraying the Roselle plants with growth stimulators significantly increased vegetative growth parameter; plant height, number of branches, branch diameter and leaf area compared to untreated plants (Table 1). 
Seaweed extract gave the tallest plants (153.8 and $141.5 \mathrm{~cm}$ ), highest number of branches (almost 10 branches per plant), widest branch diameter $(1.60$ and $1.55 \mathrm{~cm})$ and biggest leaf area $(29.10$ and $29.45 \mathrm{~cm} 2)$ for the first and second seasons, respectively. The highest calyxes yield was obtained also with plants treated with seaweed extract (Table 2) as follow; calyxes fresh weight per plant $(37.63$ and $34.50 \mathrm{~g}$ ), calyxes dry weight per plant (13.45 and $12.50 \mathrm{~g})$, calyxes fresh weight per
$2.28 \mathrm{mg} / \mathrm{g})$, chlorophyll $\mathrm{b}(0.82$ and 0.92 $\mathrm{mg} / \mathrm{g})$, carotenoids $(0.61$ and $0.65 \mathrm{mg} / \mathrm{g})$ and total chlorophyll (3.46 and $3.24 \mathrm{mg} / \mathrm{g}$ ) for the first and second seasons, respectively. In addition, it was clear that spraying plants with growth stimulators significantly increased quality of Roselle plants expressed by anthocyanin content in calyxes (Table 4). Seaweed extract gave the highest values of anthocyanin content $(7.96$ and $8.41 \mathrm{mg} / \mathrm{g}$ ) compared to the control for the first and

Table (1): Effect of salicylic acid (SA), moringa leaves extract, and seaweed extract on plant height $(\mathrm{cm})$, branch number, branch diameter $(\mathrm{cm})$, and leaf area $\left(\mathrm{cm}^{2}\right)$ in the $1^{\text {st }}$ and $2^{\text {nd }}$ seasons. Least significance difference (LSD) was calculated at probability of 0.05 .

\begin{tabular}{lllllllll}
\hline & \multicolumn{2}{c}{ Plant height } & \multicolumn{2}{c}{ Branch number } & \multicolumn{2}{c}{ Branch diameter } & \multicolumn{2}{c}{ Leaf area } \\
& $1^{\text {st }}$ & $2^{\text {nd }}$ & $1^{\text {st }}$ & $2^{\text {nd }}$ & $1^{\text {st }}$ & $2^{\text {nd }}$ & $1^{\text {st }}$ & $2^{\text {nd }}$ \\
\hline Control & $121.5^{\mathrm{a}}$ & $125.8^{\mathrm{a}}$ & $5.75^{\mathrm{a}}$ & $5.53^{\mathrm{a}}$ & $1.25^{\mathrm{a}}$ & $1.25^{\mathrm{a}}$ & $22.94^{\mathrm{a}}$ & $20.40^{\mathrm{a}}$ \\
SA & $134.3^{\mathrm{ab}}$ & $131.5^{\mathrm{b}}$ & $7.25^{\mathrm{b}}$ & $7.50^{\mathrm{b}}$ & $1.48^{\mathrm{ab}}$ & $1.33^{\mathrm{a}}$ & $25.71^{\mathrm{ab}}$ & $24.63^{\mathrm{b}}$ \\
MLE & $144.3^{\mathrm{bc}}$ & $137.0^{\mathrm{c}}$ & $8.50^{\mathrm{c}}$ & $8.75^{\mathrm{b}}$ & $1.58^{\mathrm{b}}$ & $1.50^{\mathrm{b}}$ & $28.43^{\mathrm{b}}$ & $27.33^{\mathrm{c}}$ \\
Seaweed & $153.0^{\mathrm{c}}$ & $141.5^{\mathrm{d}}$ & $9.50^{\text {cd }}$ & $9.75^{\mathrm{c}}$ & $1.60^{\mathrm{b}}$ & $1.55^{\mathrm{b}}$ & $29.10^{\mathrm{b}}$ & $29.45^{\mathrm{cd}}$ \\
\hline LSD 0.05 & 18.3 & 4.3 & 1.22 & 1.48 & 0.28 & 0.10 & 3.99 & 2.27 \\
\hline
\end{tabular}

Table (2): Effect of salicylic acid (SA), moringa leaves extract, and seaweed extract on calyxes fresh weight (FW) and dry weight (DW) per plant (g) as well as calyxes fresh weight (FW) and dry weight (DW) per Fadden $(\mathrm{kg})$ in the $1^{\text {st }}$ and $2^{\text {nd }}$ seasons. Least significance difference (LSD) was calculated at probability of 0.05 .

\begin{tabular}{lcccccccc}
\hline & \multicolumn{2}{c}{ Calyxes FW per } & \multicolumn{2}{c}{ Calyxes DW per } & \multicolumn{2}{c}{ Calyxed FW per } & \multicolumn{2}{c}{ Calyxed DW per } \\
& \multicolumn{2}{c}{ plant } & \multicolumn{2}{c}{ plant } & \multicolumn{2}{c}{ Faddan } & \multicolumn{2}{c}{ Faddan } \\
& $1^{\text {st }}$ & $2^{\text {nd }}$ & $1^{\text {st }}$ & $2^{\text {nd }}$ & $1^{\text {st }}$ & $2^{\text {nd }}$ & $1^{\text {st }}$ & $2^{\text {nd }}$ \\
\hline Control & $29.23^{\mathrm{a}}$ & $27.50^{\mathrm{a}}$ & $8.75^{\mathrm{a}}$ & $8.25^{\mathrm{a}}$ & $519.6^{\mathrm{a}}$ & $488.9^{\mathrm{a}}$ & $155.6^{\mathrm{a}}$ & $146.7^{\mathrm{a}}$ \\
SA & $32.28^{\mathrm{b}}$ & $30.25^{\mathrm{ab}}$ & $10.75^{\mathrm{b}}$ & $10.75^{\mathrm{b}}$ & $573.8^{\mathrm{b}}$ & $537.8^{\mathrm{ab}}$ & $191.1^{\mathrm{b}}$ & $191.1^{\mathrm{b}}$ \\
MLE & $34.95^{\mathrm{c}}$ & $32.25^{\mathrm{bc}}$ & $12.75^{\mathrm{c}}$ & $11.88^{\mathrm{c}}$ & $621.3^{\mathrm{c}}$ & $573.3^{\mathrm{bc}}$ & $226.7^{\mathrm{c}}$ & $211.1^{\mathrm{c}}$ \\
Seaweed & $37.63^{\mathrm{d}}$ & $34.50^{\mathrm{c}}$ & $13.45^{\text {cd }}$ & $12.50^{\text {cd }}$ & $668.9^{\mathrm{d}}$ & $613.3^{\mathrm{c}}$ & $239.1^{\text {cd }}$ & $222.2^{\text {cd }}$ \\
\hline LSD 0.05 & 1.78 & 3.07 & 0.84 & 0.96 & 31.6 & 54.5 & 15.0 & 17.1 \\
\hline
\end{tabular}

Fadden (668.9 and $613.3 \mathrm{~kg})$, and calyxes dry weight per Fadden $(239.1$ and $222.2 \mathrm{~kg}$ ) for the first and second seasons, respectively. In the same line, vegetative growth and yield associated with significantly increased in plant pigments content (Table 3). Plants treated with seaweed extract showed the highest content of chlorophyll a (2.33 and second seasons, respectively.

Natural and synthesis stimulators contribute to sustainable, high-output, and low-input crop productions. A bio-stimulant is defined as any substance or microorganism added to plants to improve nutrition efficiency, abiotic stress resistance and/or quality traits (du Jardin, 2015). 
Table (3): Effect of salicylic acid (SA), moringa leaves extract, and seaweed extract on leaf pigments; chlorophyll a, chlorophyll b, carotenoids, and total chlorophyll content $(\mathrm{mg} / \mathrm{g})$ in the $1^{\text {st }}$ and $2^{\text {nd }}$ seasons. Least significance difference (LSD) was calculated at probability of 0.05 .

\begin{tabular}{lcccccccc}
\hline & \multicolumn{2}{c}{ Chlorophyll a } & \multicolumn{2}{c}{ Chlorophyll b } & \multicolumn{2}{c}{ Carotenoids } & \multicolumn{2}{c}{ Total chlorophyll } \\
& $1^{\text {st }}$ & $2^{\text {nd }}$ & $1^{\text {st }}$ & $2^{\text {nd }}$ & $1^{\text {st }}$ & $2^{\text {nd }}$ & $1^{\text {st }}$ & $2^{\text {nd }}$ \\
\hline Control & $1.09^{\mathrm{a}}$ & $1.38^{\mathrm{a}}$ & $0.48^{\mathrm{a}}$ & $0.62^{\mathrm{a}}$ & $0.36^{\mathrm{a}}$ & $0.44^{\mathrm{a}}$ & $1.58^{\mathrm{a}}$ & $2.35^{\mathrm{a}}$ \\
SA & $1.73^{\mathrm{b}}$ & $1.83^{\mathrm{b}}$ & $0.67^{\mathrm{b}}$ & $0.77^{\mathrm{b}}$ & $0.43^{\mathrm{b}}$ & $0.55^{\mathrm{b}}$ & $2.40^{\mathrm{b}}$ & $2.60^{\mathrm{a}}$ \\
MLE & $2.08^{\mathrm{c}}$ & $1.96^{\mathrm{c}}$ & $0.80^{\mathrm{c}}$ & $0.80^{\mathrm{b}}$ & $0.53^{\mathrm{c}}$ & $0.62^{\mathrm{c}}$ & $2.88^{\mathrm{c}}$ & $2.75^{\mathrm{a}}$ \\
Seaweed & $2.33^{\mathrm{d}}$ & $2.28^{\mathrm{d}}$ & $0.82^{\text {cd }}$ & $0.92^{\mathrm{c}}$ & $0.61^{\mathrm{d}}$ & $0.65^{\text {cd }}$ & $3.46^{\mathrm{d}}$ & $3.24^{\mathrm{b}}$ \\
\hline LSD 0.05 & 0.08 & 0.07 & 0.05 & 0.10 & 0.01 & 0.04 & 0.22 & 0.41 \\
\hline
\end{tabular}

Table (4): Effect of salicylic acid (SA), moringa leaves extract, and seaweed extract on calyxes' anthocyanin content $(\mathrm{mg} / \mathrm{g})$ in the $1^{\text {st }}$ and $2^{\text {nd }}$ seasons. Least significant difference (LSD) was calculated at probability of 0.05 .

\begin{tabular}{lcc}
\hline & \multicolumn{2}{c}{ Anthocyanin } \\
& $1^{\mathrm{st}}$ & $2^{\text {nd }}$ \\
\hline Control & $5.40^{\mathrm{a}}$ & $4.04^{\mathrm{a}}$ \\
SA & $5.83^{\mathrm{ab}}$ & $5.07^{\mathrm{a}}$ \\
MLE & $7.82^{\mathrm{ab}}$ & $6.76^{\mathrm{ab}}$ \\
Seaweed & $7.96^{\mathrm{b}}$ & $8.41^{\mathrm{b}}$ \\
\hline LSD 0.05 & 2.51 & 3.06 \\
\hline
\end{tabular}

Kauffman et al. (2007) classified biostimulants into three major groups on the basis of their source as followed; (i) humic substances, (ii) hormone containing products, and (iii) amino acid containing products. On the other hand, previous studies have demonstrated that Moringa leaf extracts improve seed germination, plant growth, yield, nutrient utilization efficiency, quality characteristics of crops, as well as tolerance to abiotic stresses (Abdel-Rahman and AbdelKader, 2020; Zulfiqar et al., 2020). Moringa extracts are considered an suitable alternative source of inorganic fertilizers due to their high content of micro and macro mineral nutrients, protein and essential amino acids, which contribute to supplement the nutritional requirements of crops (Yasmeen et al., 2014). Latif and Mohamed (2016) attributed growth and yield responses when treated with Moringa to the presence of growth-promoting hormones in Moringa, as analyzes showed that Moringa extract contains antioxidants, gibberellins, IAA and ABA (Rady and Mohamed, 2015; Azam et al., 2020). The results of this study showed that seaweed extract had significantly positive effects on plant growth, yield and quality parameters. In this study, seaweed led to the highest vegetative growth, yield, pigment content and anthocyanin contents followed by moringa leaf extract. It was obvious that bio-stimulants (seaweed and moringa extracts) had better results compared to the synthesis growth stimulator (salicylic acid). Seaweed is classified as humic substance according to Kauffman et al. (2007) who explained the positive effects of seaweed in improving plant growth and quality to their containing specific amounts of active plant growth substances such as auxins, cytokinins, or their derivatives. Also, seaweed extracts include polysaccharides laminarin, alginates and carrageenans and their breakdown products as well as micro- and macronutrients (Khan et al., 2009; Craigie, 2011). 


\section{Conclusions}

From the results of this study, it can be concluded that treatment with bio-stimulants, especially seaweed extract, led to significant increases in growth, yield and quality traits. These increases may due to increases in the metabolites and chlorophyll synthesis which contribute to raising the efficiency of the photosynthesis process, compounds biosynthesis and enzymes activity for growth resulting in improving the yield traits as well as quality traits through an increase of anthocyanin synthesis. Therefore, it can be recommended to use seaweed and moringa extracts, as an effective alternatives to regular fertilization, which contributes to the sustainable development of horticultural crops.

\section{Reference}

Abdel-Rahman, S.S.A., and Abdel-Kader, A.A.S. (2020) 'Response of Fennel (Foeniculum vulgare Mill) plants to foliar application of moringa leaf extract and benzyladenine (BA)', South African Journal of Botany 129, pp. 113122. $\quad$ https://doi.org/10.1016/ j.sajb.2019.01.037

Arfan, M., Athar, H.R., and Ashraf, M. (2007) 'Does exogenous application of salicylic acid through the rooting medium modulate growth and photosynthetic capacity in differently adapted spring wheat cultivars under salt stress?' Journal of Plant Physiology 6, pp. 685-694. $\quad$ https:// doi.org/10.1016/j.jplph.2006.05.010

Arioli, T., Mattner, S.W., and Winberg, P.C. (2015) 'Applications of seaweed extracts in Australian agriculture: past, present and future', Journal of Applied Phycology 27, pp. 2007-2015. https://doi.org/10.1007/s10811015-0574-9

Azam, S., Nouman, W., Ubaid-urRehmana, Ahmed, U., Gull, T., and Shaheen, M. (2020) 'Adaptability of Moringa oleifera Lam. under different water holding capacities', South African Journal of Botany 129, pp. 299-303. https://doi.org/10.1016/j.sajb.2019.08 $\underline{020}$

Chapman, H.D., and Parattm P,F. (1961) 'Methods of Soil, Plants and Water Analysis', Univ. California, Div Agric Sci 314p.

Colla, G., and Rouphael, Y. (2015) 'Biostimulants in horticulture', Scientia Horticulturae 30 (196), pp. 1-2. https://doi.org/10.1016/j.scienta. 2015.10.044

Craigie, J.S. (2011) 'Seaweed extract stimuli in plant science and agriculture', Journal of Applied Phycology 23, pp. 371-393. $\quad$ https://doi.org/10.1007/ s10811-010-9560-4

Dhar, P., Kar, C.S., Ojha, D., Pandey, S.K., and Mitra, J. (2015) 'Chemistry, phytotechnology, pharmacology and nutraceutical functions of kenaf (Hibiscus cannabinus L.) and roselle (Hibiscus sabdariffa L.) seed oil: An overview', Industrial Crops and Products 77, pp. 323-332. https://doi. org/10.1016/j.indcrop.2015.08.064

du Jardin, P. (2015) 'Plant biostimulants: definition, concept, main categories and regulation', Scientia Horticulturae 30 (196),

pp. $3-14$. https://doi.org/10.1016/j.scienta.2015.0 9.021

Farooq, M., Aziz, T., Basra, S.M.A., Cheema, M.A., and Rehman, H. (2008) 'Chilling tolerance in hybrid maize induced by 
seed priming with salicylic acid', Journal of Agronomy and Crop Science 194, pp. 161-168. https://doi.org/10.1111/j.1439-037X. 2008.00300.x

Kauffman, G.L., Kneivel, D.P., and Watschke, T.L. (2007) 'Effects of a biostimulant on the heat tolerance associated with photosynthetic capacity, membrane thermostability, and polyphenol production of perennial ryegrass', Crop Science 47, pp. 261267.

Khalaphallah, R., and Soliman, W.S. (2014) 'Effect of henna and roselle extracts on pathogenic bacteria', Asian Pacific Journal of Tropical Disease 4, pp. 292 $296 . \quad$ https://doi.org/10.1016/S22 22-1808(14)60575-2

Khan, W., Rayirath, U.P., Subramanian, S., Jithesh, M.N., Rayorath, P., Hodges, D.M., Critchley, A.T., Craigie, J.S., Norrie, J., and Prithiviraj, B. (2009) 'Seaweed extracts as biostimulants of plant growth and development', Journal of Plant Growth Regulation 28, pp. 386-399. https://doi.org/10. 1007/s00344-009-9103-X

Latif, H.H., and Mohamed, H.I. (2016) 'Exogenous applications of moringa leaf extract effect on retro transposon, ultra structural and biochemical contents of common bean plants under environmental stresses', South African Journal of Botany 106, pp. 221-231. https://doi.org/10.1016/j. sajb.2016.07.010

Layek, J., Das, A., Idapuganti, R.G., Sarkar, D., Ghosh, A., Zodape, S.T., Lal, R., Yadav, G.S., Panwar, A.S., Ngachan, S., and Meena, R.S. (2017) 'Seaweed extract as organic bio-stimulant improves productivity and quality of rice in eastern Himalayas', Journal of
Applied Phycology 30, pp. 547-558. https://doi.org/10.1007/s10811-017$\underline{1225-0}$

Lee, J., Durst, R., and Wrolstad, R. (2005) 'Determination of total monomeric anthocyanin pigment content of fruit Juices, beverages, natural colorants, and wines by the $\mathrm{pH}$ differential method: collaborated study', Journal of AOAC International 88(5), pp. 1269-1278. https://doi.org/10.1093/ jaoac/88.5.1269

Lötze, E., and Hoffman, E.W. (2015) 'Nutrient composition and content of various biological active compounds of three South African-based commercial seaweed biostimulants', Journal of Applied Phycology 28, pp. 1379-1386. https://doi.org/10.1007/ s10811-015-0644-z

Mansori, M., Chernane, H., Latique, S., Benaliat, A., Hsissou, D., and El Kaoua, M. (2014) 'Seaweed extract effect on water deficit and antioxidative mechanisms in bean plants (Phaseolus vulgaris L.)', Journal of Applied Phycology 27, pp. 1689-1698. https://doi.org/10.1007/ s10811-014-0455-7

Metzner, H., Rau, H., and Senger, H. (1965) 'Untersuchungen zur synchronisierbarkeit einzelner. Pigment-mangel mutanten von chlorella', Planta 65, pp. 186-194. $\quad$ https://doi.org/10.1007/ BF00384998

Mzibra, A., Aasfar, A., El Arroussi, H., Khouloud, M., Dhiba, D., Kadmiri, I.M., and Bamouh, A. (2018) 'Polysaccharides extracted from Moroccan seaweed: a promising source of tomato plant growth promoters', Journal of Applied Phycology 30, pp. 2953-2962. https:// doi.org/10.1007/s 10811-018-1421-6 
Pandey, A.C.S., Sanjay, S.S., and Yadav, R. (2010) 'Application of $\mathrm{ZnO}$ nanoparticles in influencing the growth rate of Cicer arietinum', Journal of Experimental Nanoscience 5, pp. 488$497 . \quad$ https://doi.org/ $\underline{10.1080 / 17458081003649648}$

Pramanick, B., Brahmachari, K., Mahapatra, B.S., Ghosh, A., Ghosh, D., and Kar, S. (2017) 'Growth, yield and quality improvement of potato tubers through the application of seaweed sap derived from the marine alga Kappaphycus alvarezii', Journal of Applied Phycology 29, pp. 3253-3260. https://doi.org/10.1007/s10811-017$\underline{1189-0}$

Rady, M.M., and Mohamed, G.F. (2015) 'Modulation of salt stress effects on the growth, physio-chemical attributes and yields of Phaseolus vulgaris L. plants by the combined application of salicylic acid and Moringa oleifera leaf extract', Scientia Horticulturae 193, pp. 105113. https://doi.org/10.1016/j.scienta. 2015.07.003

Singh, S., Singh, M.K., Pal, S.K., Trivedi, K., Yesuraj, D., Singh, C.S., Anand, K.G.V., Chandramohan, M., Patidar, R., Kubavat, D., Zodape, S.T., and Ghosh, A. (2015) 'Sustainable enhancement in yield and quality of rain-fed maize through Gracilaria edulis and Kappaphycus alvarezii seaweed sap', Journal of Applied Phycology 28, pp. 2099-2112. https://doi.org/10.1007/s10811-015$\underline{0680-8}$
Snedecor, G.W., and Cochran, W.G. (1989) 'Statistical Methods. 8th ed.', Iowa State University Press, Ames. Iowa, USA.

Van Oosten, M.J., Pepe, O., De Pascale, S., Silletti, S., and Maggio, A. (2017) 'The role of biostimulants and bio-effectors as alleviators of abiotic stress in crop plants', Chemical and Biological Technologies in Agriculture 4, pp. 5. https://doi.org/ 10.1186/s40538-017-0089-5

Wu, H.Y., Yang, K.M., and Chiang, P.Y. (2018) 'Roselle anthocyanins: antioxidant properties and stability to heat and pH', Molecules 23, pp. 13571370. $\quad \underline{\text { https://doi.org/10. 3390/ }}$ molecules23061357

Yasmeen, A., Nouman, W., Basra, S.M.A., Wahid, A., Hussain, N., and Afzal, I. (2014) 'Morphological and physiological response of tomato (Solanum lycopersicum L.) to natural and synthetic cytokinin sources: a comparative study', Acta Physiologiae Plantarum 36, pp. 3147-3155. https://doi.org/10.1007/ s11738-014-1662-1

Zulfiqar, F., Casadesús, A., Brockman, H., and Munné-Bosch, S. (2020) 'An overview of plant-based natural biostimulants for sustainable horticulture with a particular focus on moringa leaf extracts', Plant Science 295, pp. 110194. https://doi.org/10. 1016/j.plantsci.2019.110194 